\title{
Foreign Currency Loans and Systemic Risk in Europe
}

\author{
Pınar Yeşin
}

Foreign currency loans to the unhedged non-banking sector are remarkably prevalent in Europe and create a significant exchange-rate-induced credit risk to European banking sectors. In particular, Swiss franc (CHF)-denominated loans, popular in Eastern European countries, could trigger simultaneous bank failures if depreciation of the domestic currencies prevents unhedged borrowers from servicing the loans. Foreign currency loans thus pose a systemic risk from a "common market shock" perspective. The author uses a novel dataset of foreign-currency loans from 17 countries for 2007-11 (collected by the Swiss National Bank) and builds on the method suggested by Ranciere, Tornell, and Vamvakidis (2010) to quantify this systemic risk. The author finds that systemic risk is substantial in the non-euro area, while it is relatively low in the euro area. However, CHF-denominated loans are not the underlying source of the high systemic risk: Loans denominated in other foreign currencies (probably to a large extent in euros) contribute significantly more to the systemic risk in the non-euro area than CHFdenominated loans. Furthermore, systemic risk shows high persistence and low volatility during the sample period. The author also finds that banks in Europe have continuously held more foreign-currencydenominated assets than liabilities, indicating their awareness of the exchange-rate-induced credit risk they face. (JEL F3, G2)

Federal Reserve Bank of St. Louis Review, May/June 2013, 95(3), pp. 219-35.

Pınar Yeşin is a senior economist at the Swiss National Bank and an economics lecturer at the University of Zurich. The author was a visiting scholar at the Research Division of the Federal Reserve Bank of St. Louis while working on this article and thanks colleagues there for their hospitality. The author thanks an anonymous referee; Silvio Contessi, Andreas Fischer, Steven Ongena, Adrian Peralta-Alva, B. Ravikumar, and Rajdeep Sengupta; in addition to seminar participants at the Swiss National Bank and Federal Reserve Bank of St. Louis; and conference participants at the 10th International Conference on Credit Risk Evaluation ("Stability and Risk Control in Banking, Insurance and Financial Markets") in Venice, the 9th Annual NBP-SNB Joint Seminar ("Managing Capital Flows for Monetary and Financial Stability") in Poland, the 4th International IFABS Conference ("Rethinking Banking and Finance: Money, Markets and Models") in Valencia, and the 3rd International Conference of the Turkish Economic Association ("Debt Dynamics, Financial Instability and the Great Recession") in Izmir for their helpful comments and discussions. The author also extends thanks to the 19 European central banks that participated in the Swiss National Bank's CHF Lending Monitor project and commented on an earlier version of this article.

(c) 2013, The Federal Reserve Bank of St. Louis. The views expressed in this article are those of the author(s) and do not necessarily reflect the views of the Federal Reserve System, the Board of Governors, the regional Federal Reserve Banks, or the Swiss National Bank. Articles may be reprinted, reproduced, published, distributed, displayed, and transmitted in their entirety if copyright notice, author name(s), and full citation are included. Abstracts, synopses, and other derivative works may be made only with prior written permission of the Federal Reserve Bank of St. Louis. 
when mortgage-backed securities lost significant value and simultaneously damaged the balance sheets of countless banks. And third, systemic risk can develop in the form of informational spillovers when bad news about one financial institution increases the refinancing costs of the others, which in turn increases the probability of their own collapse. 1

This article attempts to measure systemic risk in European banking sectors arising from foreign currency loans to domestic non-banks. $\underline{2}$ To do so, it adheres to the common market shock view, whereby banks could fail jointly as a result of their exposure to unhedged non-banks that borrowed in a foreign currency but have no steady income in that currency. In this case, the common market shock would be a sharp exchange rate movement triggering defaults of, for example, domestic households on their foreign-currency-denominated mortgages. Such a shock would lead to a simultaneous deterioration of the financial condition of numerous banks in Europe because they hold sizable foreign currency loans to domestic households on the asset side of their balance sheets and have short-term foreign currency liabilities in the interbank market.

Foreign currency loans are remarkably prevalent in Europe. Figure 1 shows that in 2011:Q3 the majority of the outstanding loans to the non-banking sector in the non-euro area countries were denominated in a foreign currency. For example, in Hungary, Bulgaria, and Romania, more than 60 percent of the outstanding loans to non-banks are denominated in a foreign currency.

Even if borrowing in euros might be considered rational for some non-euro area countries that are "closer" to adopting the euro, $\underline{3}$ many other European countries will not officially join the euro area for several more years. Moreover, there is a considerable amount of borrowing in foreign currencies other than the euro by the non-banking sector in Europe. For example, loans denominated in Swiss francs (CHF) constitute a significant share of total loans in some countries, such as Austria, Croatia, Hungary, and Poland (see Figure 1).

Remarkably, the European household sector in particular is borrowing in foreign currencies. 4 Figure 2 shows the sectoral breakdown of CHF loans to the non-banking sector as of 2011:Q3. Note that in almost all countries in the sample, more than 40 percent of the outstanding CHF loans are made to the domestic household sector (the exceptions are the Czech Republic, the United Kingdom, Germany, and Luxembourg). Only in the United Kingdom and Luxembourg is a large share of CHF loans made to nonresidents, $\underline{5}$ reflecting the status of these countries as international financial centers.

Therefore, foreign currency loans in Europe are mainly considered "small men's carry trade": Households (and small firms) borrow in a lower-yielding foreign currency and invest in a highyielding domestic currency (e.g., in the form of a home mortgage or car loan). While doing so, they expect the domestic currency to continue to appreciate as it did in the past, a recurring violation of the uncovered interest parity condition. $\underline{6}$

While borrowing in a foreign currency offers some immediate benefits-such as lower interest rates and longer maturities-for the non-banking sector, these loans also carry a significant exchange rate risk. The domestic household sector is unlikely to have any income in a foreign currency or to use sophisticated hedging instruments against the exchange rate risk because of the lack of hedging instruments, willing counterparties, or deep financial markets. The fact that the household sector is unhedged manifests itself, for example, in the nonexistence of forward 


\section{Figure 1}

\section{Share of Foreign Currency Loans as a Percentage of Total Loans to the Non-Banking Sector} in Europe (2011:Q3)

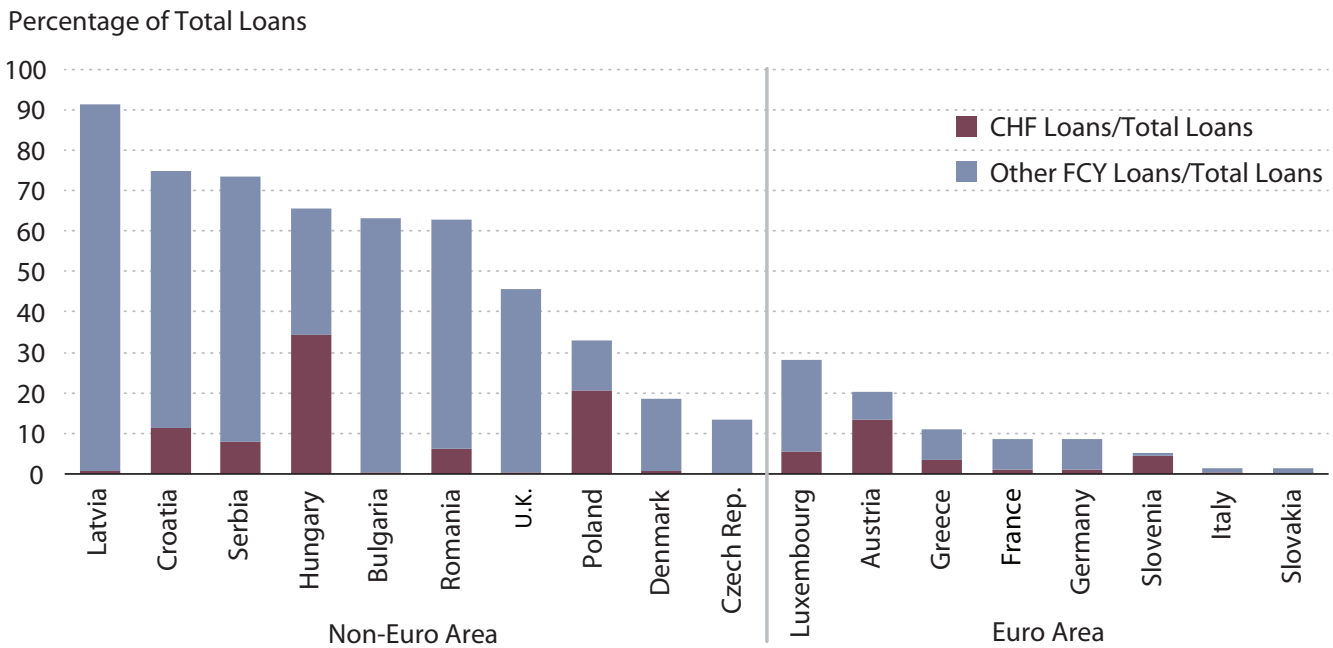

NOTE: CHF, Swiss francs; FCY, foreign currency.

SOURCE: CHF Lending Monitor.

Figure 2

Sectoral Breakdown of CHF Loans to the Non-Banking Sector (2011:Q3)

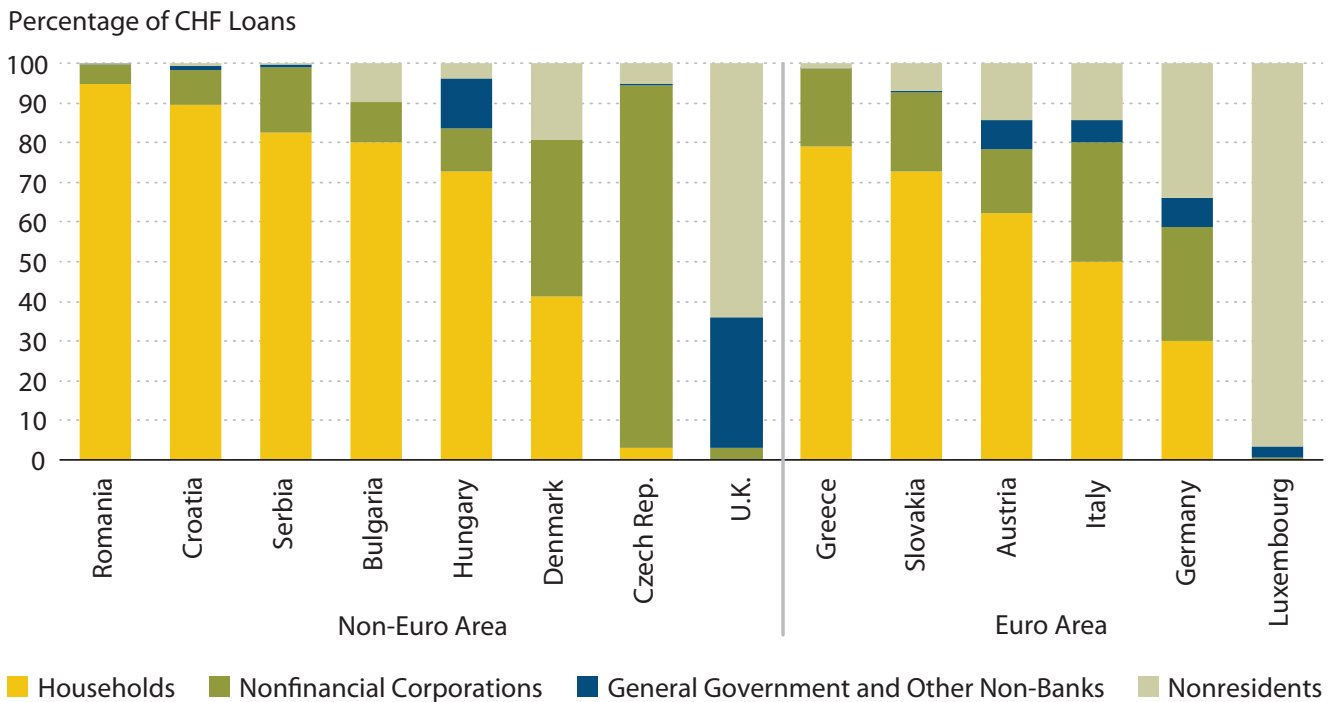

NOTE: CHF, Swiss francs.

SOURCE: CHF Lending Monitor. 
exchange rates of the Eastern European currencies vis-à-vis the CHF. To hedge against the exchange rate risk, a household in Eastern Europe with a mortgage denominated in CHF would need to take two hedging positions: one vis-à-vis the euro and another one between the euro and the CHF. Since each hedging instrument also entails a transaction cost, the "profit" from borrowing in a low-yielding currency would simply vanish in this case. There are no studies in the literature that document the hedging behavior of households borrowing in foreign currencies. However, Pann, Seliger, and Übeleis (2010) refer to a survey by the Austrian Central Bank and state that "foreign currency lending to naturally hedged households in CESEE [Central, Eastern, and Southeastern Europe] and the CIS [Commonwealth of Independent States] was negligible (lower than 10 percent)."

Therefore, a sharp depreciation of the domestic currency can prevent borrowers from being able to service their foreign currency loans. $\frac{8}{}$ As a result, the sizable foreign currency loans on banks' balance sheets can pose a significant systemic risk.

The European Systemic Risk Board (ESRB), an independent European Union (EU) institution monitoring financial stability within the EU, recognized the systemic risk that foreign currency loans pose to European banking sectors and made an official recommendation on lending in foreign currency on November 22, 2011. 9 In particular, the ESRB stated the following:

(1) Foreign currency lending to unhedged borrowers has increased in a number of Union Member States.

(2) Excessive foreign currency lending may produce significant systemic risks for those Member States and may create conditions for negative cross-border spillover effects.

Similarly, the Hungarian Financial Supervisory Authority voiced its concerns regarding systemic risk arising from foreign currency loans in the Hungarian banking sector in 2011 and advised the banks in Hungary to swap the CHF-denominated loans into euro loans to reduce the systemic risk (Reuters, 2011). In fact, new foreign currency loans to non-banks have been prohibited in Hungary since the summer of 2010. However, the outstanding foreign currency loans to non-banks still pose a significant risk to the economy and Hungarian authorities have been working on a plan to contain it.

The European Bank for Restructuring and Development (EBRD) also acknowledged foreign currency loans in the EBRD region $\underline{10}$ as a "key vulnerability" and therefore launched a major initiative in 2010 to develop local currency and capital markets to help reduce unhedged foreign currency borrowing (see ERBD, 2010).

While policymakers in Europe repeatedly express their concern regarding the systemic risk created by foreign currency loans, $\underline{11}$ there is a lack of literature on the exact measurement of this systemic risk. The previous literature cannot answer questions such as the following:

- What is the magnitude of the systemic risk for European banking sectors arising from foreign currency loans to the non-banking sector?

- To what extent would the banking sectors' balance sheets be affected if the (unhedged) non-banking sector could no longer service its foreign currency debt because of a sudden exchange rate movement? 
- Are CHF-denominated loans the main driver of a systemic risk in certain countries, as perceived by policymakers and the general public?

This article attempts to fill this void in the literature by using a novel dataset of foreign currency loans in Europe and building on a method suggested by Ranciere, Tornell, and Vamvakidis (2010). The Swiss National Bank (SNB) has collected quarterly data on foreign currency loans from 19 European central banks since 2009 under its CHF Lending Monitor project.

"Systemic risk measure" is defined here as the impact of writing down the unhedged foreign currency loans on banks' balance sheets. This measure takes into account the indirect exchange rate risk that banks take on when they lend to unhedged borrowers (i.e., domestic households and nonfinancial corporations). In particular, it calculates the net unhedged foreign currency liabilities as a share of total assets. The larger this number is in a given country, the higher is the systemic risk in its banking sector.

The four distinct contributions of this article to the literature are as follows:

(i) Since data from the CHF Lending Monitor are reliable and consistent across countries and are more detailed than the information that has been publicly available until now, these new systemic risk measures are more accurate than those in Ranciere, Tornell, and Vamvakidis (2010).

(ii) I can separately identify the aggregate systemic risk arising from all foreign currency loans and the particular systemic risk resulting from CHF loans in Europe.

(iii) A sectoral breakdown of systemic risk is possible in this dataset.

(iv) The quarterly data of the CHF Lending Monitor allow me to observe the evolution of the currency mismatch on a quarterly basis from 2009:Q1 until 2011:Q3. For a subset of countries, the measure can be calculated as far back as 2002:Q1. $\underline{12}$

First, I find that the systemic risk arising from foreign currency loans is quite high in the majority of the non-euro area countries: Net unhedged foreign currency liabilities of the banking sectors correspond to more than 20 percent of their total assets. However, net unhedged CHF liabilities never exceed more than 5 percent of their total assets. Therefore, I conclude that $\mathrm{CHF}$ loans are not the main driver of a systemic risk in Europe, despite the common belief that CHF loans pose the greatest threat among foreign currency loans.

Second, the sectoral breakdown of systemic risk shows that banks attempt to hedge against the foreign-currency-induced credit risk by persistently holding more foreign currency assets than foreign currency liabilities on their balance sheets. However, the mere size of the foreign currency loans to unhedged households exceeds this buffer in most countries, resulting in a positive and, in certain countries, sizable systemic risk.

Third, I find that systemic risk has been quite persistent and nonvolatile in Europe since 2007. That is, short-term policies would be unable to swiftly reduce that systemic risk. This also confirms the findings of previous research that non-banks take long-term loans in foreign currency and are not involved in short-term speculative carry trade activity based solely on shortterm changes in the macroeconomic environment. $\underline{13}$ 
This article is structured as follows: The next section provides an overview of the previous literature on foreign currency loans and systemic risk. The two following sections explain the method and the data used, respectively. The findings are then laid out, with conclusions and policy implications discussed in the final section of the article.

\section{PREVIOUS LITERATURE}

The previous literature on foreign currency borrowing focuses mostly on household-, firm-, or bank-level survey data to understand the factors at play. A common finding is that households and small firms may engage in excessive risk-taking because (i) they do not necessarily have foreign currency income and (ii) foreign banks in Eastern Europe may be a driver of foreign currency loans in the region. For example, Brown, Ongena, and Yeşin (2011) study firm- and country-level determinants of foreign currency borrowing by small firms in transition countries. Although they find that firms with foreign currency income are more likely to borrow in foreign currency, local currency earners also borrow in foreign currency to a significant degree. Similarly, Beer, Ongena, and Peter (2010) empirically analyze foreign currency borrowing by households in Austria and find that risk-seeking, affluent, and married households are more likely to take a housing loan denominated in a foreign currency. Brown, Kirschenmann, and Ongena (2011), on the other hand, study loan application and approval data at a bank in Bulgaria; they find that foreign currency borrowing may be partly supply driven by banks hesitant to give longterm loans in the local currency. $\cdot \underline{14}$ Furthermore, Brown, Ongena, and Yeşin (2013) show in a simple banking model that persistent violation of the uncovered interest parity may lead to more foreign currency borrowing in equilibrium if the banks have imperfect information about the revenue level and currency of borrowing firms. Similarly, Degryse et al. (2012) find that foreign banks that entered the emerging markets through greenfield investment tend to extend more loans in foreign currency, possibly because of their easier access to foreign currency funding in international money markets. All in all, the existing literature on foreign currency loans points to the emergence of a systemic risk in European banking sectors. $\underline{15}$

In this article, systemic risk corresponds to the joint failure of several banks as a result of their exposure to a common market shock (i.e., the simultaneous default of unhedged foreign currency borrowers as the result of a sharp exchange rate movement) because banks tend to hold similar assets on their balance sheets. Undoubtedly, contagion by way of the interbank market or information spillovers among banks could represent a significant part of the systemic risk arising from foreign currency loans. However, the emerging literature on systemic risk since the financial crisis perceives common shocks as an equally important threat to the system and highlights the need to further understand their source and their impact. For example, Acharya and Yorulmazer (2008) show that banks herd and undertake correlated investments to minimize the impact of information contagion on the expected cost of borrowing. Such herding among banks would lead to greater exposure of the financial system to a common shock.

Currently, available data are insufficient to conduct a contagion analysis in this regard. Cerutti, Claessens, and McGuire (2011) argue that systemic risk analysis is very difficult, even impossible, with the existing bank-level data and suggest the collection of consistent bank-level 
data showing aggregate positions and linkages to appropriately measure and monitor systemic risk both within countries and across borders. Therefore, this article adopts the common shock approach rather than the contagion or informational spillover perspective to measure the systemic risk arising from foreign currency loans.

\section{METHOD}

I build on the approach suggested by Ranciere, Tornell, and Vamvakidis (2010) to calculate a measure of systemic risk for European countries' banking sectors. This systemic risk measure calculates the net unhedged foreign currency liabilities as a percentage of total assets and can be characterized, in fact, as a novel currency mismatch index. This customized currency mismatch index takes into account the indirect exchange rate risk that banks assume when they lend to unhedged borrowers. In other words, it considers the "exchange-rate-induced credit risk" and is an evaluation of the currency mismatch on the balance sheets of European banking sectors in the case of a joint failure of households (and nonfinancial corporations) to service their foreign currency loans resulting from a sharp appreciation of the foreign currency.

In the existing literature, currency mismatch in a banking sector is usually measured as the net foreign currency liabilities (i.e., the difference between foreign currency liabilities and foreign currency assets) as a share of the total assets of the banking sector. However, banks usually match their foreign currency assets and foreign currency liabilities so that their difference would be almost (or sometimes by regulation identical to) zero. Furthermore, this simple measure treats all foreign currency assets equally without considering the risks associated with foreign currency loans given to unhedged borrowers.

Therefore, Ranciere, Tornell, and Vamvakidis (2010) propose calculating the net foreign currency liabilities as a share of total assets, but excluding the "risky" foreign currency assets from the foreign currency assets. In other words, foreign currency loans given to the domestic 16 non-banking sector are not included in total foreign currency assets. Thus, in a given country the foreign currency mismatch index in the banking sector is equal to net foreign-currencydenominated liabilities plus unhedged foreign currency assets divided by total assets. Therefore,

Foreign currency mismatch index $=$

$\frac{\text { FCY liabilities-(FCY assets-FCY loans to resident households and nonfinancial corporations) }}{\text { Total assets }}$

where FCY denotes foreign currency.

As detailed information on CHF-denominated loans is available in the CHF Lending Monitor, the same method can be applied to calculate the systemic risk arising from CHF loans only. Thus,

CHF mismatch index $=$ CHF liabilities-(CHF assets-CHF loans to resident households and nonfinancial corporations)

Total assets

Similarly, 
Other FCY mismatch index $=$

Other FCY liabilities-(Other FCY assets-Other FCY loans to resident households and nonfinancial corporations)

Total assets

Note that

Foreign currency mismatch index $=$ CHF mismatch index + Other FCY mismatch index.

Furthermore, these indexes can be broken down into three components: net foreign currency liabilities, foreign currency loans to households, and foreign currency loans to nonfinancial corporations, all as a share of total assets. In other words, a sectoral breakdown of systemic risk is possible.

Note also that the mismatch indexes are upper bounds for the systemic risk because they assume that none of the domestic households or nonfinancial corporations can service their foreign currency debt. More detailed information on each country regarding the characteristics of domestic borrowers can certainly refine these indexes. That is, instead of using the share of foreign currency loans by all domestic borrowers, the share of foreign currency loans by domestic borrowers with no foreign currency income can be entered into the equation to derive a more precise measure of systemic risk. However, these data are not available in the CHF Lending Monitor; therefore, in this article, I can calculate only the upper bounds for the systemic risk for each country.

There are a few possible extensions and refinements to this measure of systemic risk. One possible extension would be to vary the "default rate" of the borrowers in relation to the magnitude of the depreciation and calculate an elasticity of systemic risk vis-à-vis the exchange rate. This extension would rely on the nonperforming loan ratios of individual countries in the past. Another possible extension would be to use this approach for individual banks rather than the entire banking system. National central banks and/or financial market regulators could have access to bank-level data in their own countries and easily calculate this systemic risk measure for individual banks. This extension could help policymakers identify banks that are most exposed to the common shock, as well as banks that contribute significantly to the systemic risk. Because such bank-level data are not available to the author and/or are confidential, these extensions can be analyzed only in possible future works.

\section{DATA}

All data are from the CHF Lending Monitor, which is an ongoing SNB project to understand the scope of CHF lending in Europe. Nineteen European central banks ${ }^{17}$ have been sharing their aggregate banking sector statistics with the SNB quarterly since 2009. The data are confidential and have not been published publicly. A quarterly report based on these data is circulated among the participating central banks. This report provides an overview of the volume, structure, and refinancing of CHF loans by banks domiciled in European countries to their non-banking clients.

The CHF Lending Monitor data consist of aggregate banking sector statistics on both the asset side (such as loans and other assets) and the liability side (such as deposits, own securities 
issues, and other liabilities). The sectoral breakdown of loan and deposit data is available for the following categories: resident banks, $\underline{18}$ resident households, resident nonfinancial corporations, resident government, nonresident banks, and nonresident non-banks. Furthermore, a currency breakdown of loans, deposits, and own securities issued is available for the following categories: domestic currency, CHF, and other foreign currency.

Such detailed aggregate-level information on the banking sector's assets and liabilities makes it possible to accurately calculate the systemic risk arising from a foreign currency shock. Furthermore, the data are precise, as they rely on central banks' reporting and do not involve an uninformed estimation. $\frac{19}{}$

Central banks are asked to provide quarterly data for 92 variables in total; however, the central banks are free to decide to withhold certain variables because of confidentiality or unavailability of certain banking statistics. As a result of this data limitation, the foreign currency mismatch index can be calculated for 17 countries in the sample, and the CHF mismatch index can be calculated for 13 countries.

\section{FINDINGS}

Table 1 lists the measures for systemic risk across countries in Europe as of 2011:Q3. It also shows the currency breakdown of systemic risk between the CHF mismatch index and the other foreign currency (Other FCY) mismatch index. ${ }^{20}$ First, note that the foreign currency mismatch index varies significantly across European countries: from -0.8 percent in France to 44.3 percent in Latvia. It is generally higher in the non-euro area than in the euro area. For example, in all non-euro area countries except the Czech Republic and the United Kingdom, the foreign currency mismatch index is between 14 percent and 45 percent. In other words, net unhedged foreign currency liabilities of the banking sectors constitute between 14 percent and 45 percent of their total assets. Consequently, there is high systemic risk in the banking sectors of these countries. On the other hand, in the euro area countries the foreign currency mismatch index is lower by comparison. Net unhedged foreign currency liabilities always constitute less than 3.2 percent of total banking sector assets.

Interestingly, the CHF mismatch index is fairly low in all European countries. For example, in Croatia the foreign currency mismatch index is 36.7 percent, but only 4.4 percent is due to loans denominated in CHF. The rest of the systemic risk is due to loans denominated in other foreign currencies (the mismatch index for other foreign currency in Croatia is 32.3 percent). Also, in other countries with a relatively high foreign currency mismatch index, the CHF mismatch index is relatively quite low. Thus, CHF loans to households and nonfinancial corporations are not the main driver behind the high systemic risk in the non-euro area countries. Consequently, loans denominated in other foreign currencies (probably denominated to a large extent in euros $\underline{21}$ ) contribute far more to systemic risk in most non-euro area countries.

Table 2 shows the individual components-that is, the sectoral breakdown - of the foreign currency mismatch index across European countries. These components are net foreign currency liabilities, foreign currency loans to domestic households, and foreign currency loans to domestic nonfinancial corporations (all as a share of total assets). The table reveals that most 


\section{Table 1}

Systemic Risk Indexes in Europe Arising From Foreign Currency Loans (2011:Q3)

\begin{tabular}{|c|c|c|c|}
\hline Region/Country & $\begin{array}{c}\text { FCY } \\
\text { mismatch index (\%) }\end{array}$ & $\begin{array}{c}\text { CHF } \\
\text { mismatch index (\%) }\end{array}$ & $\begin{array}{c}\text { Other FCY } \\
\text { mismatch index (\%) }\end{array}$ \\
\hline \multicolumn{4}{|l|}{ Non-euro area } \\
\hline Latvia & 44.3 & NA & NA \\
\hline Croatia & 36.7 & 4.4 & 32.3 \\
\hline Serbia & 31.8 & 1.9 & 29.8 \\
\hline Romania & 29.6 & 2.3 & 27.3 \\
\hline Bulgaria & 26.6 & 0.0 & 26.6 \\
\hline Hungary & 21.1 & 3.7 & 17.4 \\
\hline Poland & 14.3 & NA & NA \\
\hline Czech Republic & 3.5 & -0.2 & 3.7 \\
\hline United Kingdom & -0.1 & 0.0 & 0.0 \\
\hline \multicolumn{4}{|l|}{ Euro area } \\
\hline Slovenia & 3.1 & 3.1 & 0.1 \\
\hline Austria & 2.2 & 0.8 & 1.3 \\
\hline Greece & 1.6 & -0.4 & 2.0 \\
\hline Slovakia & 1.1 & NA & NA \\
\hline Germany & 0.6 & -0.1 & 0.7 \\
\hline Luxembourg & 0.2 & -0.7 & 1.0 \\
\hline Italy & 0.1 & 0.0 & 0.1 \\
\hline France & -0.8 & NA & NA \\
\hline
\end{tabular}

banking sectors in the non-euro area are possibly trying to hedge against the exchange rate risk by holding (significantly) more foreign currency assets than foreign currency liabilities. However, the volume of foreign currency loans to domestic households and nonfinancial corporations is fairly large relative to their total assets. Therefore, the resulting currency mismatch indexes are substantial in several non-euro area countries.

The high systemic risk in the non-euro area countries is due to two factors: (i) The banking sectors in those countries have sizable foreign currency assets (and liabilities) relative to their total assets. (ii) Foreign currency loans to domestic households and nonfinancial corporations constitute a very large portion of the foreign currency assets.

Similarly, Table 3 displays the sectoral composition of the CHF mismatch index in 2011:Q3 across Europe. As shown in Table 1, the CHF mismatch index, and hence the systemic risk resulting from $\mathrm{CHF}$ loans, is relatively low in all countries. However, in a few countries, the low mismatch index is due to banks holding significantly more CHF assets than CHF liabilities (particularly prevalent in Hungary, Croatia, and Austria). These net CHF assets compensate for 


\section{Table 2}

Components of the Foreign Currency Mismatch Index (2011:Q3)

\begin{tabular}{|c|c|c|c|c|}
\hline Region/Country & $\begin{array}{l}\text { Net FCY liabilities/ } \\
\text { Total assets (\%) }\end{array}$ & $\begin{array}{c}\text { FCY loans } \\
\text { to domestic } \\
\text { households/ } \\
\text { Total assets (\%) }\end{array}$ & $\begin{array}{c}\text { FCY loans to } \\
\text { domestic nonfinancial } \\
\text { corporations/ } \\
\text { Total assets }(\%)\end{array}$ & $\begin{array}{c}\text { FCY } \\
\text { mismatch index (\%) }\end{array}$ \\
\hline \multicolumn{5}{|l|}{ Non-euro area } \\
\hline Latvia & -6.4 & 24.0 & 26.7 & 44.3 \\
\hline Croatia & -6.8 & 23.2 & 20.3 & 36.7 \\
\hline Serbia & -5.8 & 13.2 & 24.5 & 31.8 \\
\hline Romania & -5.6 & 17.3 & 17.8 & 29.6 \\
\hline Bulgaria & -12.9 & 8.9 & 30.6 & 26.6 \\
\hline Hungary & -7.7 & 16.4 & 12.4 & 21.1 \\
\hline Poland & -5.6 & 15.3 & 4.6 & 14.3 \\
\hline Czech Republic & 0.3 & 0.0 & 3.2 & 3.5 \\
\hline United Kingdom & -0.5 & 0.0 & 0.5 & -0.1 \\
\hline \multicolumn{5}{|l|}{ Euro area } \\
\hline Slovenia & 0.0 & 2.4 & 0.7 & 3.1 \\
\hline Austria & -2.9 & 3.8 & 1.2 & 2.2 \\
\hline Greece & -3.9 & 1.6 & 4.0 & 1.6 \\
\hline Slovakia & 0.6 & 0.5 & 0.0 & 1.1 \\
\hline Germany & -0.2 & 0.1 & 0.6 & 0.6 \\
\hline Luxembourg & 0.1 & 0.0 & 0.2 & 0.2 \\
\hline Italy & -0.3 & 0.1 & 0.4 & 0.1 \\
\hline France & -1.4 & 0.2 & 0.4 & -0.8 \\
\hline
\end{tabular}

NOTE: The FCY mismatch index is the sum of the following three components: net FCY liabilities, FCY loans to domestic households, and FCY loans to domestic nonfinancial corporations (all as a share of total assets). FCY, foreign currency.

SOURCE: Author's calculations based on CHF Lending Monitor data.

the sizable CHF loans to domestic borrowers in those countries. Consequently, the resulting CHF mismatch index is relatively low. Without such compensation for the risk, the CHF mismatch would have been much higher.

Figures 3 and 4 show the time evolution of systemic risk in Europe. Note that both the foreign currency mismatch index and the CHF mismatch index have been fairly persistent over time for most countries and show no large fluctuations during the period for which data are available.

In Figure 3, the foreign currency mismatch index reveals an upward trend in a few countries (e.g., Latvia, Bulgaria, Romania, and Poland) in the first half of the sample period. However, the index remains fairly flat or declines slowly in the second half of the sample period. In the remaining non-euro area countries, it is fairly stable during the period observed. Figure 4 similarly shows high persistence and low volatility of the foreign currency mismatch index in the euro area, albeit at a much lower level of systemic risk. 


\section{Table 3}

Components of the CHF mismatch index (2011:Q3)

\begin{tabular}{|c|c|c|c|c|}
\hline Region/Country & $\begin{array}{l}\text { Net CHF liabilities/ } \\
\text { Total assets (\%) }\end{array}$ & $\begin{array}{c}\text { CHF loans } \\
\text { to domestic } \\
\text { households/ } \\
\text { Total assets (\%) }\end{array}$ & $\begin{array}{c}\text { CHF loans to } \\
\text { domestic nonfinancial } \\
\text { corporations/ } \\
\text { Total assets }(\%)\end{array}$ & $\begin{array}{c}\text { CHF } \\
\text { mismatch index (\%) }\end{array}$ \\
\hline \multicolumn{5}{|l|}{ Non-euro area } \\
\hline Croatia & -3.2 & 6.9 & 0.7 & 4.4 \\
\hline Hungary & -12.8 & 14.4 & 2.1 & 3.7 \\
\hline Romania & -1.3 & 3.5 & 0.2 & 2.3 \\
\hline Serbia & -2.7 & 3.9 & 0.8 & 1.9 \\
\hline Bulgaria & -0.2 & 0.2 & 0.0 & 0.0 \\
\hline United Kingdom & 0.0 & 0.0 & 0.0 & 0.0 \\
\hline Czech Republic & -0.2 & 0.0 & 0.0 & -0.2 \\
\hline \multicolumn{5}{|l|}{ Euro area } \\
\hline Slovenia & 0.0 & 2.4 & 0.7 & 3.1 \\
\hline Austria & -3.6 & 3.5 & 0.9 & 0.8 \\
\hline Italy & -0.1 & 0.1 & 0.0 & 0.0 \\
\hline Germany & -0.3 & 0.1 & 0.1 & -0.1 \\
\hline Greece & -2.3 & 1.5 & 0.4 & -0.4 \\
\hline Luxembourg & -0.7 & 0.0 & 0.0 & -0.7 \\
\hline
\end{tabular}

Finally, Figures 5 and 6 depict the time evolution of the CHF mismatch index across Europe. Again, persistency and low volatility of the systemic risk can be observed. A few countries, such as Croatia and Hungary, do show a slight upward trend in the CHF mismatch index over time; however, the CHF mismatch index remains at much lower levels than the foreign currency mismatch index during the sample period.

\section{CONCLUSION AND SOME POLICY IMPLICATIONS}

In this article, I have quantified the systemic risk in European countries resulting from foreign currency loans from a "common market shock" perspective. For this purpose, I used data from the CHF Lending Monitor and built on the method suggested by Ranciere, Tornell, and Vamvakidis (2010). These accurate, frequent, and detailed measurements of systemic risk in the form of more-precise currency mismatch indexes may give policymakers a finer gauge of the systemwide risks associated with foreign currency loans.

I find that the systemic risk in the banking sector is very high in a majority of the non-euro area countries: Net unhedged foreign currency liabilities of the banking sectors correspond to 


\section{Figure 3}

\section{Foreign Currency Mismatch Index in the Non-Euro Area}

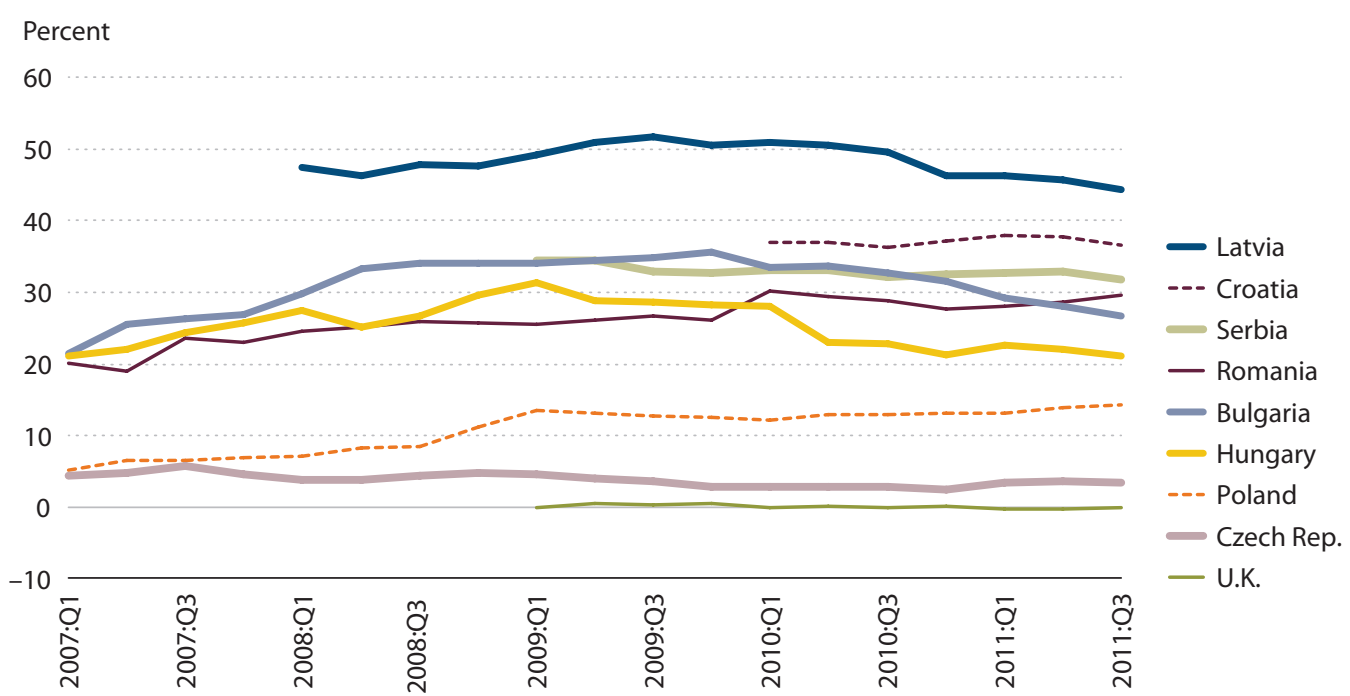

Figure 4

Foreign Currency Mismatch Index in the Euro Area

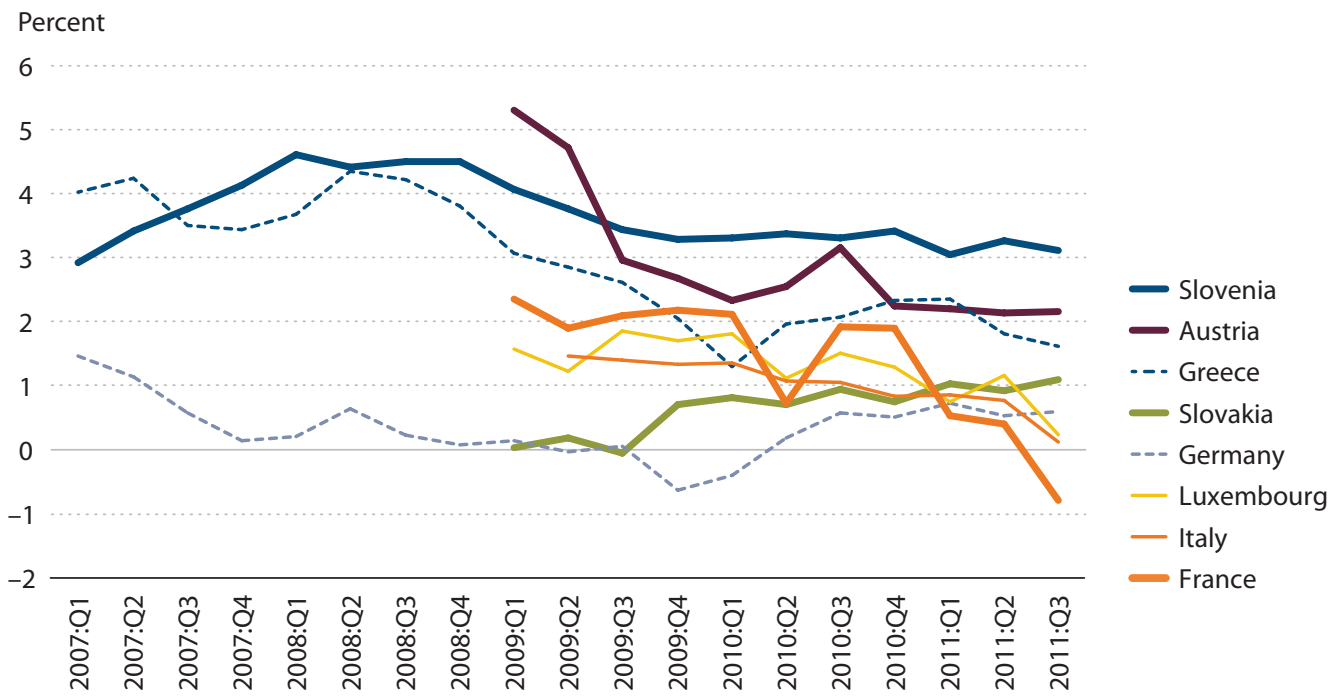

SOURCE: Author's calculations based on CHF Lending Monitor data. 
Figure 5

\section{CHF Mismatch Index in the Euro Area}

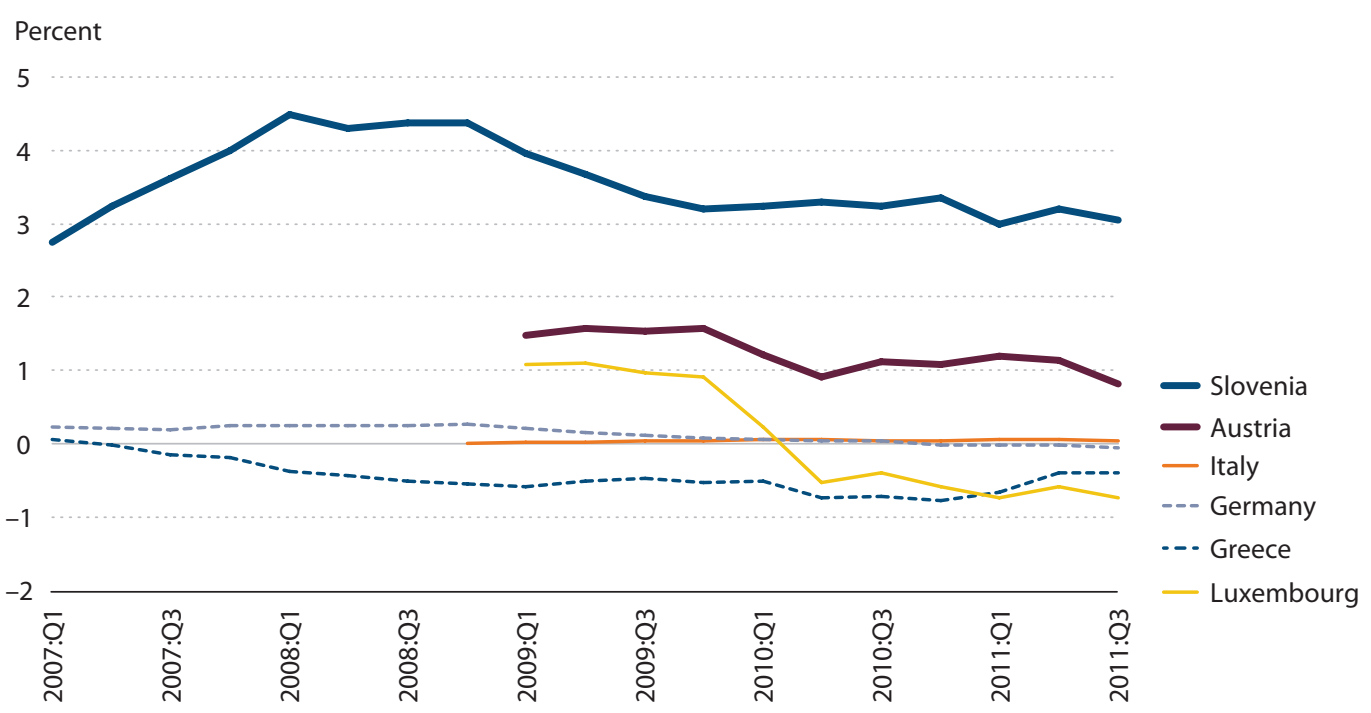

NOTE: CHF, Swiss francs.

SOURCE: Author's calculations based on CHF Lending Monitor data.

\section{Figure 6}

\section{CHF Mismatch Index in the Non-Euro Area}

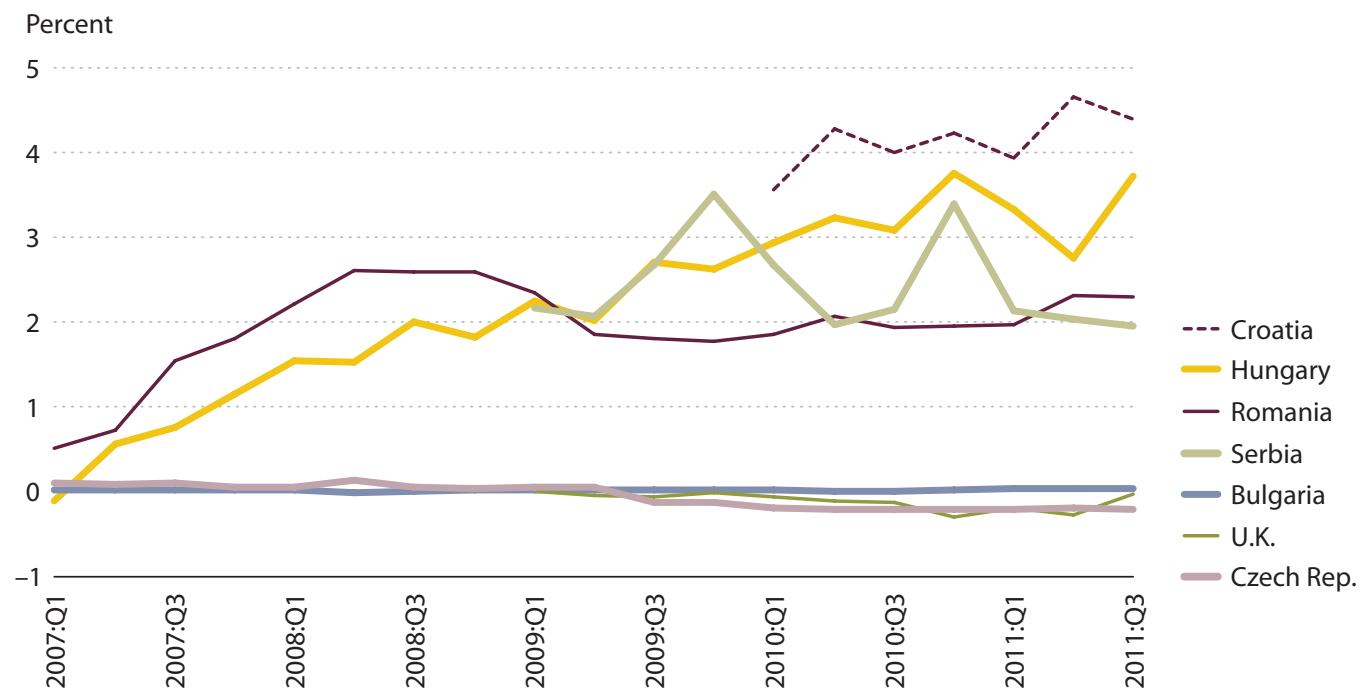

NOTE: CHF, Swiss francs.

SOURCE: Author's calculations based on CHF Lending Monitor data. 
more than 20 percent of their total assets as of 2011:Q3. However, net unhedged CHF liabilities amount to less than 5 percent of their total assets. Thus, other foreign currency loans (probably to a large extent in euros) contribute to systemic risk far more than the CHF loans in the noneuro area. Switching the CHF loans into euro loans, as was recently suggested by the Hungarian Financial Supervisory Authority, would therefore not eliminate the systemic risk resulting from foreign currency loans.

Furthermore, foreign currency mismatch indexes show persistence and low volatility during the sample period for which they can be calculated. That is, short-term policies would be unable to swiftly reduce that systemic risk. Encouragement of local currency borrowing, on the other hand, can be a long-run solution, as recently promoted by the EBRD initiative (see EBRD, 2010).

A sectoral breakdown of systemic risk indicates that banks may be aware of the exchangerate-induced credit risk they assume when they lend to unhedged borrowers. This is evident from their balance sheets, which contain significantly more foreign currency assets than foreign currency liabilities.

Last but not least, the role of the European Central Bank as the lender of last resort within the European Union (and not only within the euro area) needs to be discussed among the policymakers. In the non-euro area countries, where "euroization" took place unofficially within the financial system before the formal adoption of the euro, significant threats can materialize suddenly in the case of sharp exchange rate movements. A sizable depreciation of the non-euro area currencies vis-à-vis the euro can irreversibly damage the balance sheets of banks resident in the non-euro area.

\section{NOTES}

1 See, for example, De Bandt and Hartmann (2000) and Georg (2011a,b) for an in-depth discussion of systemic risk. See Schwaab, Koopman, and Lucas (2011) for systemic risk diagnostics.

$\underline{2}$ The non-banking sector consists of these subsectors: households, nonfinancial corporations, non-bank financial institutions, general government, and nonprofit institutions serving households (see the European System of Accounts, 1995; http://circa.europa.eu/irc/dsis/nfaccount/info/data/ESA95/en/esa95en.htm).

3 As of March 2013, there are only three currencies in the Exchange Rate Mechanism II (ERM II): the Danish krone, Latvian lat, and Lithuanian litas. According to the European Commission, "Participation in ERM II is voluntary, although, as one of the convergence criteria for entry to the euro area, a country must participate in the mechanism without severe tensions for at least two years before it can qualify to adopt the euro" (from "What is ERM II?"; http://ec.europa.eu/economy finance/euro/adoption/erm2/index en.htm). The Danish krone has been in the ERM II since 1999, but Denmark has no specific plans to join the euro area. Latvia is not expected to join the euro area before 2014. Its currency, the Latvian lat, has been in the ERM II since 2005. The Lithuanian litas has been in the ERM II since 2004; however, Lithuania is also not expected to join the euro area before 2014.

4 Previous literature documents that large corporations traditionally borrow in foreign currencies in many countries in East Asia and Latin America (e.g., see Allayannis, Brown, and Klapper, 2003, and Galindo, Panizza, and Schiantarelli, 2003). However, retail borrowing in foreign currencies in Europe is a more recent development.

$\underline{5}$ Nonresidents are entities (such as households and nonfinancial corporations) residing in a country other than where their banks are domiciled.

6 See Galati, Heath, and McGuire (2007) on the recent buildup of carry trade positions resulting from low exchange rate volatility and persistent interest rate differentials. The literature on the uncovered interest parity is vast. Francis, Hasan, and Hunter (2002), for example, find persistent violation of the uncovered interest parity in emerging market economies. 
1 See Pann, Seliger, and Übeleis (2010) for a discussion on risks to the Austrian banking sector as a result of their foreign currency lending in Central, Eastern, and Southeastern Europe.

$\underline{8}$ For example, this became an important issue during the financial crisis when the Hungarian forint and Polish złoty depreciated sharply and both the stock and the ratio of nonperforming loans rose in the portfolios of banks.

9 See the EBRD recommendations at http://www.esrb.europa.eu/pub/pdf/recommendations/2011/ESRB 2011_1.en. pdf?3304c9df8c9cecd453b4ecbab95d359d.

10 The EBRD region consists of the transition countries in Eastern Europe and the CIS countries (the former USSR).

11 During the financial crisis, when many Eastern European currencies depreciated significantly, many borrowers could no longer service their foreign currency debt. Nonperforming loan ratios increased during the crisis and policymakers were concerned about the systemic threat these foreign currency loans pose to the banking sector.

12 This article reports only systemic risk measures since 2007.

13 Brown, Ongena, and Yeşin (2011) find that foreign currency borrowing by small firms in transition countries is much more strongly related to firm-level foreign currency revenues than to country-level interest rate differentials.

14 Brown and de Haas (2012) also provide a similar finding.

15 On foreign currency loans in Europe, see also Fidrmuc, Hake, and Stix (2011) and Cuaresma, Fidrmuc, and Hake (2011).

16 Domestic $=$ resident. $\mathrm{A}$ resident bank is a bank domiciled in that country. It can be a domestically owned bank or a subsidiary of a foreign bank.

17 The 19 contributing central banks are those in Austria, Bulgaria, Croatia, the Czech Republic, Denmark, Estonia, France, Germany, Greece, Hungary, Italy, Latvia, Luxembourg, Poland, Romania, Serbia, Slovakia, Slovenia, and the United Kingdom.

18 All central banks started reporting in 2009. At that time, some central banks also submitted their previous data going back to 2002:Q1.

19 Data received from the United Kingdom include some estimated sector split information.

20 The currency mismatch indexes cannot be calculated for Denmark as data on the banking sector's liabilities are missing. In this article, the currency mismatch indexes for Estonia are also not shown because Estonia adopted the euro during the sample period. Furthermore, $\mathrm{CHF}$ and other foreign currency mismatch indexes cannot be calculated for France, Latvia, Poland, and Slovakia because of missing data.

21 Further breakdown of currencies is not available in the CHF Lending Monitor; hence the euro mismatch index in the non-euro area countries cannot be calculated separately.

\section{REFERENCES}

Acharya, Viral L. and Yorulmazer, Tanju. "Information Contagion and Bank Herding." Journal of Money, Credit, and Banking, February 2008, 40(1), pp. 215-31.

Allayannis, George; Brown, Gregory W. and Klapper, Leora F. “Capital Structure and Financial Risk: Evidence from Foreign Debt Use in East Asia." Journal of Finance, December 2003, 58(6), pp. 2667-709.

Beer, Christian; Ongena, Steven and Peter, Marcel. “Borrowing in Foreign Currency: Austrian Households as Carry Traders." Journal of Banking and Finance, September 2010, 34(9), pp. 2198-211.

Brown, Martin and De Haas, Ralph. "Foreign Banks and Foreign Currency Lending in Emerging Europe." Economic Policy, January 2012, 27(69), pp. 57-98.

Brown, Martin; Kirschenmann, Karolin and Ongena, Steven. "Foreign Currency Loans—Demand or Supply Driven?" Working Paper No. 2011-2, Swiss National Bank, 2011; http://www.snb.ch/n/mmr/reference/working_paper_2011 02/source.

Brown, Martin; Ongena, Steven and Yeşin, Pınar. "Foreign Currency Borrowing by Small Firms in the Transition Economies." Journal of Financial Intermediation, 2011, 20(3), pp. 285-302. 
Brown, Martin; Ongena, Steven and Yeşin, Pınar. "Information Asymmetry and Foreign Currency Borrowing by Small Firms." Comparative Economic Studies. Published electronically April 25, 2013; http://www.palgrave-journals.com/ces/journal/vaop/ncurrent/pdf/ces20139a.pdf or doi:10.1057/ces.2013.9.

Cerutti, Eugenio; Claessens, Stijn and McGuire, Patrick. "Systemic Risks in Global Banking: What Available Data Can Tell Us and What More Data Are Needed?" IMF Working Paper No. 11/222, International Monetary Fund, September 2011; http://www.imf.org/external/pubs/ft/wp/2011/wp11222.pdf.

Cuaresma, Jesús Crespo; Fidrmuc, Jarko and Hake, Mariya. “Determinants of Foreign Currency Loans in CESEE Countries: A Meta-Analysis." Focus on European Economic Integration, 2011, 4, pp. 69-87.

De Bandt, Olivier and Hartmann, Philipp. "Systemic Risk: A Survey." ECB Working Paper No. 35, European Central Bank, November 2000; http://www.ecb.int/pub/pdf/scpwps/ecbwp035.pdf.

Degryse, Hans; Havrylchyk, Olena; Jurzyk, Emilia and Kozak, Sylwester. “Foreign Bank Entry, Credit Allocation and Lending Rates in Emerging Markets: Empirical Evidence from Poland." Journal of Banking and Finance, November 2012, 36(11), pp. 2949-59.

European Bank for Reconstruction and Development. "Local Currency Initiative: EBRD Launches Local Currency and Local Capital Markets Initiative." May 15, 2010; http://www.ebrd.com/pages/news/press/2010/100515a.shtml.

Fidrmuc, Jarko; Hake, Mariya and Stix, Helmut. “Households' Foreign Currency Borrowing in Central and Eastern Europe." Working Paper No. 171, Austrian Central Bank, July 2011; http://www.oenb.at/de/img/wp171_tcm14-239053.pdf.

Francis, Bill B.; Hasan, Iftekhar and Hunter, Delroy M. “Emerging Market Liberalization and the Impact on Uncovered Interest Rate Parity." Journal of International Money and Finance, November 2002, 21(6), pp. 931-56.

Galati, Gabriele; Heath, Alexandra and McGuire, Patrick. "Evidence of Carry Trade Activity." Bank for International Settlements Quarterly Review, September 2007, 33, pp. 27-41; http://www.bis.org/publ/qtrpdf/r qt0709e.pdf.

Galindo, Arturo J.; Panizza, Ugo and Schiantarelli, Fabio. “Debt Composition and Balance Sheet Effects of Currency Depreciation: A Summary of the Micro Evidence." Emerging Markets Review, December 2003, 4(4), pp. 330-39.

Georg, Co-Pierre. “Basel III and Systemic Risk Regulation-What Way Forward?" Working Papers on Global Financial Markets No. 17-2011, Friedrich-Schiller-University Jena, January 2011a; http://pubdb.wiwi.uni-jena.de/pdf/wp hlj17-2011.pdf.

Georg, Co-Pierre. "The Effect of the Interbank Network Structure on Contagion and Common Shocks." Discussion Paper Series 2: Banking and Financial Studies, No. 12/2011, Deutsche Bundesbank, 2011 b; http://www.bundesbank.de/Redaktion/EN/Downloads/Publications/Discussion_Paper_2/2011/2011_10_25_dkp_1 2.pdf? blob=publicationFile.

Pann, Johannes; Seliger, Reinhardt and Übeleis, Julia. "Foreign Currency Lending in Central, Eastern and Southeastern Europe: The Case of Austrian Banks." Financial Stability Report, December 2010, 20, pp. 56-76.

Ranciere, Romain; Tornell, Aaron and Vamvakidis, Athanasios. "Currency Mismatch, Systemic Risk and Growth in Emerging Europe." Economic Policy, October 2010, 25(64), pp. 597-658.

Reuters. "UPDATE 1-Hungary Watchdog Proposes Switch to EUR-Based Loans." January 11, 2011; http://www.reuters.com/article/2011/01/11/hungary-loans-idUSLDE70A17S20110111.

Schwaab, Bernd; Koopman, Siem Jan and Lucas, André. "Systemic Risk Diagnostics: Coincident Indicators and Early Warning Signals." Working Paper Series No. 1327, European Central Bank, October 2011; http://www.ecb.int/pub/pdf/scpwps/ecbwp1327.pdf. 
